\title{
Morphophysical pedotransfer functions for groundwater pollution by nitrate leaching in Central Chile
}

\author{
Ignacio Fuentes $^{1 *}$, Manuel Casanova ${ }^{1}$, Oscar Seguel ${ }^{1}$, Francisco Nájera $^{1}$, and Osvaldo Salazar ${ }^{1}$
}

\begin{abstract}
Nitrate leaching (NL) is a major concern in agriculture due to its impact on human health and ecosystems. Solute movement through soil is governed by various hydraulic and physical properties that determine water flow. To study such relationships, a pedotransfer function of groundwater pollution was developed in two alluvial irrigated soils under long-term pig slurry applications. Two basins of central Chile, San Pedro (Typic Xerochrepts) and Pichidegua (Mollic Xerofluvents) were selected, where maize (Zea mays L.) was grown in spring-summer, while during autumn-winter period a ryegrass-barleyoat mixed crop was established in San Pedro and a fallow management applied in Pichidegua. Soils in cultivated and control sites were characterized in physical and hydraulic terms. Nitrogen and water budgets were determined measuring periodically (biweekly) $\mathrm{N}$ concentration $\left(\mathrm{N}_{-} \mathrm{NO}_{3}{ }^{-}\right.$and $\left.\mathrm{N}-\mathrm{NH}_{4}{ }^{+}\right)$and monitoring water contents in soil profiles, respectively. Dye tracer tests were performed with brilliant blue (BB) dye and the staining patterns analyzed. To contrast the effect of slurry additions over soil physical properties and over NL, $t$-Student tests were performed. Some accurate pollution groundwater NL pedotransfer functions were obtained calculated through least square fit models and artificial neural networks. Textural porosity, mean diameter variation, slow drainage porosity, air conductivity at $33 \mathrm{kPa}$ water tension and $\mathrm{N}-\mathrm{NO}_{3}{ }^{-}$concentrations were directly related to NL. In terms of preferential flow analysis, stained path width $>200 \mathrm{~mm}$ was inversely associated to NL. Finally, dye tracer tests provided a better understanding of the characteristics and pattern of water/solute movement through soil to groundwater.
\end{abstract}

Key words: Nitrate leaching index, preferential flow, soil hydraulic properties.

\section{INTRODUCTION}

The major concern of slurry application in agriculture is the potential risk of groundwater pollution through nitrate leaching (NL), eutrophication of surface waters and biosphere damages (Vahtera et al., 2007). Slurry has a high proportion of total $\mathrm{N}$ in soluble or readily mineralizable form and NL occurs especially when $\mathrm{N}$ application rates exceed crop uptake rates (Harter et al., 2002). On the other hand, preferential flow in soils has become an important environmental issue with increased attention over the hydrology processes, contaminant leaching, pollution of water bodies in agriculture (Jarvis, 2007) and ecosystem services (Clothier et al., 2008).

Pedotransfer functions (PTFs) are a form to present mathematical functional relationships and transforming information of the main soil properties into information on the parameters of water transfer in soil (Shein and

${ }^{1}$ Universidad de Chile, Facultad de Ciencias Agronómicas, Casilla 1004, Santiago, Chile.

*Corresponding author (ignacio.fuentes.sanroman@gmail.com). Received: 18 September 2013.

Accepted: 3 June 2014.

doi:10.4067/S0718-58392014000300013
Arkhangel'skaya, 2006). However, during the last years PTFs are used not only in soil hydrophysics but also in all branches of soil science for describing any mathematical relationships between soil properties. Thus, by the use of PTFs, NL can be predicted through physical, hydraulic, and morphometric soil properties revealed from dye staining patterns to establish risk zones and to restrict land management practices (inefficient fertilization and irrigation management) linked to $\mathrm{N}$ fate and availability (Buczko et al., 2010).

Despite the progress in image analysis techniques that facilitate quantitative examination of the link between texture and morphology of soil horizons, no attempts have been made to link qualitative analyses of dye tracer experiments with the hydrodynamic aspects in terms of water movement (Alaoui et al., 2011). I turn, a number of approaches have been used to quantify the factors influencing the transfer of $\mathrm{NO}_{3}{ }^{-}$from terrestrial to aquatic systems, including budget calculations, processbased models and statistical analyses (Salemi et al., 2011; Mastrocicco et al., 2013). The present study aims to develop a pedotransfer function of groundwater $\mathrm{NO}_{3}$ pollution on two alluvial irrigated soils of central Chile under long-term pig slurry applications considering these relationships between morphophysical soil properties and nitrate leaching. 


\section{MATERIALS AND METHODS}

The experimental sites are located on two basins within the central valley of Chile, named Pichidegua (UTM 0277313E, 6194387S) and San Pedro (UTM 0289587E, 6240288S; Datum WGS 1984 19S).

\section{Characteristics of Pichidegua experimental sites}

Pichidegua presents deep and very stratified alluvial soils (Mollic Xerofluvent; Casanova et al., 2013) in a Semiarid Mediterranean climate $\left(\approx 700 \mathrm{~mm} \mathrm{yr}^{-1}\right.$; Pizarro et al., 2012). The soils selected, defined as Pichidegua Slurry (PS), were irrigated, cultivated with maize ( $\mathrm{Zea}$ mays L.) during spring-summer period, and under fallow management and continuous pig slurry applications during autumn-winter in the last 10 -yr. The mean $\mathrm{N}$ concentration in the pig slurry applied was $1.3 \mathrm{~g} \mathrm{~L}^{-1}$ and the volume applied on each occasion was approximately $500 \mathrm{~m}^{3} \mathrm{ha}^{-1}$, supplying a dose of $640 \mathrm{~kg} \mathrm{~N} \mathrm{ha}^{-1}$ (11 July and 1 August 2011). Soils of the same cartographic unit under the same management practices, but without slurry/ fertilizer additions, defined as Pichidegua Control (PC), were also studied.

Soils from PS presented sandy loam surface textural classes with loamy sand and silty loam horizons at 50 and $100 \mathrm{~cm}$, respectively, whilst PC presented silty loam surface horizons that graded into sandy loam textural classes with depth. The surface soil organic matter contents (SOM) in PS ranked $5.3 \%$ and $6.2 \%$ in PC without significant differences due to tillage practices. In both experimental sites SOM decreased with depth and related directly to clay contents. Surface soil bulk densities (Bd) were 1.33 $\mathrm{Mg} \mathrm{m}^{-3}$ in PS and $1.10 \mathrm{Mg} \mathrm{m}^{-3}$ in PC, increasing with depth and with sand content in both sites.

\section{Characteristics of San Pedro experimental sites}

San Pedro has deep and stratified alluvial soils (Typic Xerochrepts) developed over alluvial fans in a Semiarid climate $\left(\approx 400 \mathrm{~mm} \mathrm{yr}^{-1}\right)$. The experimental units were carried out in soils irrigated and with a crop rotation management of maize, during spring-summer, and ryegrass-barley-oat mixed in autumn-winter. An experimental site, defined as San Pedro Slurry (SS), was under continuous pig slurry applications during a 5-yr period, but without slurry additions during the study period. Other experimental site with the same characteristics and in the same cartographic unit, but with no slurry or fertilizer applications, defined as San Pedro Control (SC), was also selected and assessed (Table 1).

A basic physical soil characterization in San Pedro showed sandy loam surface textural classes in SS, with an intercalated sandy horizon at $50 \mathrm{~cm}$, whilst SC presented sandy loam textural classes in the entire profile. Soil $\mathrm{OM}$ in the surface of SS experimental site ranked 3.2\%, decreasing with depth and Bd in surface was $1.32 \mathrm{Mg} \mathrm{m}^{-3}$, increasing with depth. In SC, surface SOM content ranked
Table 1. General description of conditions at the two study sites in central Chile.

\begin{tabular}{lclccl}
\hline Sites $^{\mathrm{a}}$ & Basin & $\begin{array}{l}\text { Soil } \\
\text { classification }\end{array}$ & $\begin{array}{l}\text { Soil } \\
\text { use }^{\mathrm{b}}\end{array}$ & Applications & $\begin{array}{c}\text { Last } \\
\text { management }\end{array}$ \\
\hline PS & Pichidegua & $\begin{array}{l}\text { Mollic } \\
\text { Xerofluvent }\end{array}$ & Fallow & Pig slurry & $\begin{array}{l}\text { Conventional } \\
\text { tillage - maize }\end{array}$ \\
PC & & & Control & \\
\hline SS & San Pedro & $\begin{array}{l}\text { Typic } \\
\text { Xerochrept }\end{array}$ & RCB & Pig slurry & $\begin{array}{l}\text { Conventional } \\
\text { tillage - rotation }\end{array}$ \\
SC & & MAP & Control & None \\
\hline
\end{tabular}

apS: Pichidegua with slurry additions; PC: Pichidegua control; SS: San Pedro with slurry additions; SC: San Pedro control.

${ }^{\mathrm{b}} \mathrm{RCB}$ : ryegrass-barley-oat mix; MAP: Mediterranean annual prairie.

$3.0 \%$ and decreased with depth, whilst Bd in surface was considerably high $\left(1.43 \mathrm{Mg} \mathrm{m}^{-3}\right)$, decreasing with depth.

\section{Experimental sites and nitrate leaching calculations}

Experimental sites consisted of four experimental units (replication plots) of $5 \times 5 \mathrm{~m}^{2}$ separated from each other by $5 \mathrm{~m}$, where five in situ $\mathrm{N}$ mineralization tubes and one frequency domain reflectometry (FDR) access tube for water content monitoring were distributed in each experimental plot. Besides, in each experimental plot, according to morphological descriptions, soil sampling was done at depth intervals of $0-10,25-35,50-60$, and $100-110 \mathrm{~cm}$ for $\mathrm{N}$ measurement $\left(\mathrm{N}^{-} \mathrm{NO}_{3}{ }^{-}\right.$and $\left.\mathrm{N}-\mathrm{NH}_{4}{ }^{+}\right)$ analyses by the steam distillation method described by Sadzawka et al. (2006) using soil coring collected every 2 wk with three replicates per experimental plot.

From undisturbed soil samples taken at regular depth intervals in each experimental plot, soil pore size distribution (Figure 1), air permeability and saturated hydraulic conductivity were previously characterized (Table 2). Besides, structural and textural porosity calculations are presented in Figure 2. In order to complement the physical soil properties assessed, soil macroaggregate stability (Hartge and Horn, 1992) and soil microaggregate stability (Berryman et al., 1982) were also determined.

In situ $\mathrm{N}$ mineralization tubes consisted of covered PVC cylinders with holes for fluid exchange (five replicates per plot), which were collected monthly to assess in situ soil $\mathrm{N}$ mineralization-immobilization rates and cumulative net $\mathrm{N}$ mineralization, determined as the difference between final and initial inorganic $\mathrm{N}$ content (Kolberg et al., 1997). A positive value indicated that mineralization process had dominated, while a negative value denoted that immobilization had exceeded mineralization. To estimate $\mathrm{NL}$, the following $\mathrm{N}$ budget was used:

$$
\mathrm{NL}_{\text {budget }}=\Delta \mathrm{N}\left(\mathrm{NO}_{3}+\mathrm{NH}_{4}\right) \pm \mathrm{MIT}-\mathrm{Cex}-\mathrm{GL}
$$
where $\mathrm{NL}_{\text {budget }}$ corresponds to nitrate leached from the corresponding measuring depth, $\Delta \mathrm{N}\left(\mathrm{NO}_{3}+\mathrm{NH}_{4}\right)$ represents the difference in plant-available $\mathrm{N}$ between two consecutive dates, MIT corresponds to the gross mineralization-immobilization turnover from organic $\mathrm{N}$ through the study season, Cex represents the $\mathrm{N}$ output due to crops (uptake and harvesting) and GL to gaseous losses (volatilization and denitrification). 

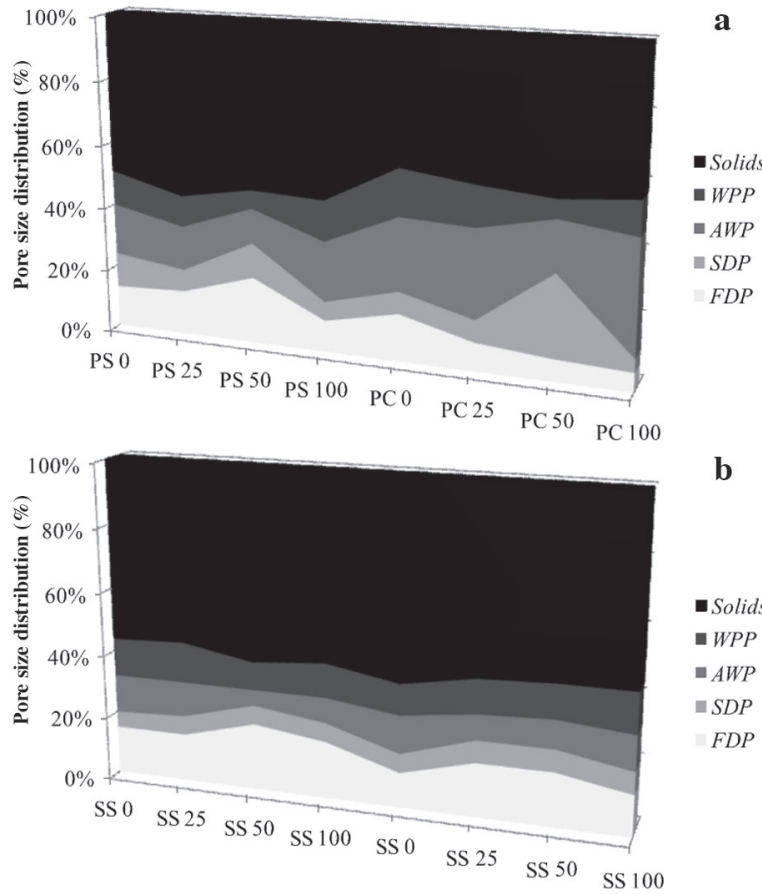

PS: Pichidegua with slurry additions; PC: Pichidegua control; SS: San Pedro with slurry additions; SC: San Pedro control.

Figure 1. Solids and pore size distribution (WPP: wilting point pores, AWP: available water pores, SDP: slow drainage pores, FDP: fast drainage pores) in depth for soils of central Chile. (a) Pichidegua soil and (b) San Pedro soil, with and without pig slurry applications.

Nitrate leaching was then calculated as the sum of $\mathrm{N}-\mathrm{NO}_{3}{ }^{-}$and $\mathrm{N}-\mathrm{NH}_{4}{ }^{+}$concentrations between consecutive dates when: a) the water budget confirmed that there was deep percolation and, b) the $\mathrm{N}$ difference at 100 $110 \mathrm{~cm}$ depth was negative $\left(\mathrm{N}_{\text {final }}-\mathrm{N}_{\text {initial }}\right)$, assuming that at such depth $\mathrm{N}$ was leached beyond root depth. In a modified version of the method used by Scheffer and Ortseifen (1997), MIT and Cex were subtracted from
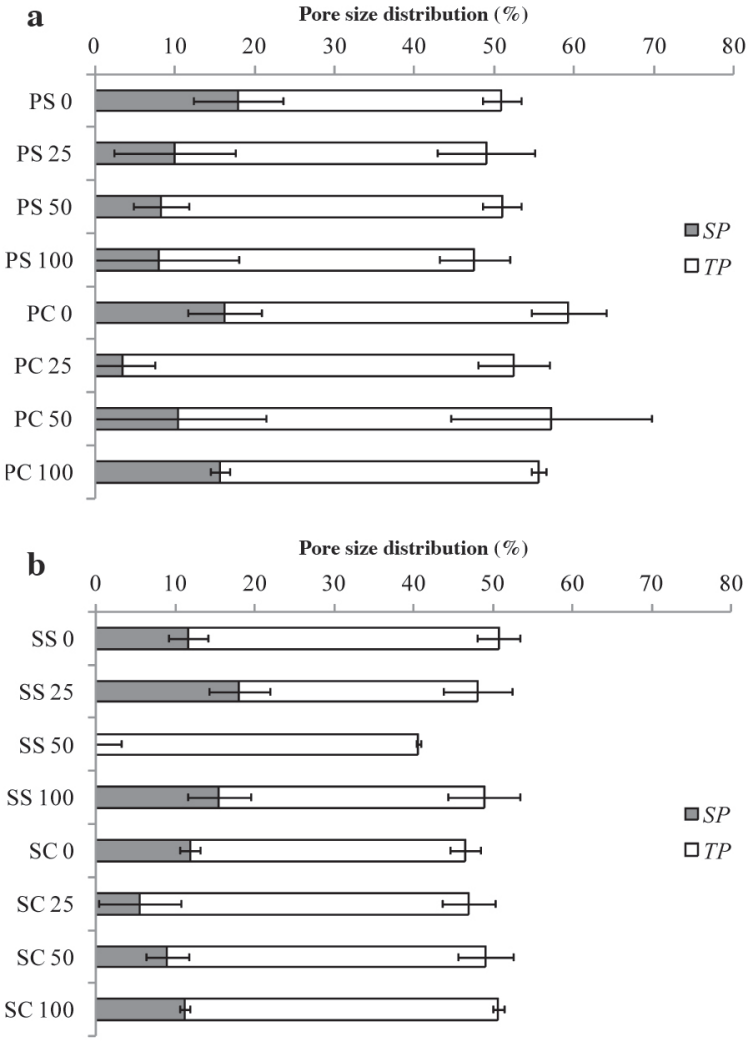

PS: Pichidegua with slurry additions; PC: Pichidegua control; SS: San Pedro with slurry additions; SC: San Pedro control.

Figure 2. Structural (SP) and textural (TP) pore distribution in depth for two soils of central Chile with and without pig slurry applications. (a) Pichidegua soils; (b) San Pedro soils.

the $\mathrm{N}$ budget between $0-10$ and $25-35 \mathrm{~cm}$ to obtain $\mathrm{NL}$ values, but not for deeper samples due to the decrease in mineralization (Kleber et al., 2000) and plant uptake with depth. In addition, NL obtained through the $\mathrm{N}$ balance was compared with a model of nitrate movement

Table 2. Conductive soil properties within two soil series of central Chile.

\begin{tabular}{|c|c|c|c|c|c|c|c|c|}
\hline \multirow[b]{2}{*}{ Soil } & \multicolumn{5}{|c|}{ Saturated hydraulic conductivity $(\mathrm{a}, \mathrm{b})$} & \multicolumn{3}{|c|}{ Air conductivity } \\
\hline & $\mathrm{Ks} 2$ & $\mathrm{Ks} 4$ & $\mathrm{Ks} 8$ & Ks24 & $\mathrm{Ks} 30$ & Ka6 & Ka33 & Ka100 \\
\hline & & & $\mathrm{m} \mathrm{d}^{-1}$ & & & $\longrightarrow$ & $\mathrm{m} \mathrm{d}^{-1}$ & \\
\hline PS 0 & $51.57 \pm 91.37$ & $46.55 \pm 85.17$ & $18.14 \pm 24.29$ & $18.44 \pm 26.96$ & $30.53 \pm 54.86$ & $16.79 \pm 7.67$ & $27.83 \pm 16.24$ & $16.06 \pm 8.90$ \\
\hline PS 25 & $2.97 \pm 2.99$ & $2.12 \pm 1.56$ & $1.47 \pm 1.06 b$ & $0.75 \pm 0.49 b$ & $0.58 \pm 0.39$ & $13.47 \pm 6.19$ & $20.80 \pm 13.82$ & $4.62 \pm 1.56$ \\
\hline PS 50 & $4.53 \pm 3.73$ & $3.11 \pm 2.03$ & $2.24 \pm 1.56$ & $1.70 \pm 0.92$ & $1.90 \pm 1.06$ & $17.53 \pm 15.58$ & $24.81 \pm 17.63$ & $13.62 \pm 7.12$ \\
\hline PS 100 & $0.37 \pm 0.23$ & $0.43 \pm 0.50$ & $0.37 \pm 0.22$ & $0.35 \pm 0.17$ & $0.49 \pm 0.26$ & $26.95 \pm 9.82$ & $19.43 \pm 8.71$ & $7.48 \pm 5.56$ \\
\hline PC 0 & $0.73 \pm 0.80$ & $0.63 \pm 0.61$ & $0.40 \pm 0.31$ & $0.40 \pm 0.38$ & $0.36 \pm 0.34$ & $37.51 \pm 15.76$ & $15.01 \pm 13.76$ & $25.22 \pm 12.26$ \\
\hline PC 25 & $0.46 \pm 0.71$ & $0.24 \pm 0.35$ & $0.12 \pm 0.15 a$ & $0.11 \pm 0.14 \mathrm{a}$ & $0.16 \pm 0.18$ & $21.91 \pm 14.93$ & $11.48 \pm 11.57$ & $11.68 \pm 6.50$ \\
\hline PC 50 & $1.74 \pm 1.35$ & $1.55 \pm 1.26$ & $1.44 \pm 1.33$ & $1.39 \pm 1.50$ & $1.32 \pm 1.31$ & $24.31 \pm 15.40$ & $11.91 \pm 4.03$ & $9.02 \pm 5.91$ \\
\hline PC 100 & $7.45 \pm 8.59$ & $10.75 \pm 16.06$ & $9.70 \pm 15.92$ & $8.38 \pm 15.32$ & $6.29 \pm 11.67$ & $18.69 \pm 9.94$ & $33.56 \pm 20.08$ & $25.98 \pm 19.65$ \\
\hline SS 0 & $14.53 \pm 14.45$ & $7.97 \pm 6.76$ & $6.84 \pm 6.73$ & $3.05 \pm 3.42$ & $2.90 \pm 3.07$ & $10.31 \pm 2.32$ & $17.87 \pm 20.36$ & $7.95 \pm 3.08$ \\
\hline SS 25 & $1.72 \pm 1.85$ & $1.36 \pm 1.49$ & $0.56 \pm 0.17$ & $0.46 \pm 0.33$ & $0.75 \pm 0.65$ & $15.70 \pm 13.30$ & $19.46 \pm 12.17$ & $10.36 \pm 5.16$ \\
\hline SS 50 & $38.90 \pm 38.71$ & $36.56 \pm 38.35$ & $31.01 \pm 35.37$ & $3.98 \pm 4.79$ & $3.73 \pm 4.61$ & $26.45 \pm 23.70$ & $15.26 \pm 10.31$ & $7.36 \pm 4.05$ \\
\hline SS 100 & $7.87 \pm 9.62$ & $6.43 \pm 8.58$ & $2.82 \pm 3.66$ & $2.58 \pm 3.50$ & $2.83 \pm 3.77$ & $31.01 \pm 24.59$ & $27.67 \pm 18.63$ & $9.69 \pm 5.16$ \\
\hline SC 0 & $4.57 \pm 6.55$ & $4.23 \pm 6.26$ & $3.16 \pm 4.62$ & $1.66 \pm 1.95$ & $1.90 \pm 2.24$ & $19.21 \pm 15.28$ & $28.61 \pm 24.90$ & $9.55 \pm 4.41$ \\
\hline SC 25 & $1.21 \pm 0.86$ & $1.03 \pm 0.79$ & $0.91 \pm 0.70$ & $0.63 \pm 0.26$ & $0.62 \pm 0.37$ & $7.47 \pm 4.87$ & $6.27 \pm 3.21$ & $9.10 \pm 3.57$ \\
\hline SC 50 & $4.25 \pm 2.62$ & $4.17 \pm 2.56$ & $3.28 \pm 1.76$ & $2.52 \pm 1.15$ & $1.85 \pm 0.73$ & $8.11 \pm 2.38$ & $9.49 \pm 7.14$ & $17.99 \pm 14.65$ \\
\hline SC 100 & $8.92 \pm 16.07$ & $8.35 \pm 15.31$ & $5.23 \pm 9.09$ & $2.13 \pm 3.03$ & $2.00 \pm 3.06$ & $10.84 \pm 7.79$ & $9.73 \pm 4.54$ & $15.95 \pm 9.38$ \\
\hline
\end{tabular}

PS: Pichidegua with slurry additions; PC: Pichidegua control; SS: San Pedro with slurry additions; SC: San Pedro control.

${ }^{a}$ Different lower-case letters within depths for soils (same basin) denote significant differences $(p<0.05)$.

${ }^{b} \mathrm{Ksx}$ is saturated hydraulic conductivity at $\mathrm{x}$ hours, Kay is air conductivity at $\mathrm{y}$ water tension (kPa). 
in soils (Matus and Rodríguez, 1994). In San Pedro soil, vegetal tissues were collected for total $\mathrm{N}$ estimations and DM production to obtain the $\mathrm{N}$ exported (Sadzawka et al., 2007), while in Pichidegua the fallow management restricted plant growth.

\section{Water budget in experimental sites}

At each site a simplified water budget was defined using climate data from nearby meteorological centers (Pichidegua station: $34^{\circ} 21^{\prime} 34^{\prime \prime} \mathrm{S}, 7^{\circ} 17^{\prime} 59^{\prime \prime} \mathrm{W}$; San Pedro station: $33^{\circ} 56^{\prime} 29^{\prime \prime} \mathrm{S}, 71^{\circ} 23^{\prime} 39^{\prime \prime} \mathrm{W}$ ) and according to Equation [2]:

$$
\pm \mathrm{DP} \text { or } \mathrm{C}=\mathrm{I}+\mathrm{R}-(\Delta \theta+\mathrm{ETc})
$$

where DP is deep percolation (positive values), $\mathrm{C}$ is capillary rise (negative values), $\mathrm{I}$ is irrigation, $\mathrm{R}$ is rainfall and ETc corresponds to crop evapotranspiration, respectively $\left(\mathrm{m}^{3} \mathrm{ha}^{-1}\right.$ or $\left.\mathrm{mm}\right)$. Runoff was considered negligible due to the coarse-textured upper soil horizon and the low slope gradient $(<1 \%)$ of sites. Soil water content $(\theta)$ was determined with a FDR device (Diviner 2000-Series II, Sentek Sensor Technologies, Stepney, South Australia, Australia) every $2 \mathrm{wk}$ and $\Delta \theta$ represents the temporal change in volumetric soil water content $\left(\theta_{t+1}\right.$ $\left.-\theta_{\mathrm{t}}, \mathrm{cm}^{3} \mathrm{~cm}^{-3}\right)$.

\section{Preferential flow analysis}

The preferential flow (PF) pathways were examined in open pits at each experimental unit after Brilliant blue (BB) dye tracer application. A load of BB solution (2.2 $\mathrm{g} \mathrm{L}^{-1}$ ) was applied within sub-plots (metal frame square) of $1.5 \mathrm{~m}^{2}$ until reach soil saturation at $100 \mathrm{~cm}$ depth. Subsequently, a soil pit was excavated and stained areas were morphometrically assessed under natural daylight conditions and without direct radiation. Pictures of soil profiles were taken with a digital camera (Sony DSLR-A100; resolution: 10.2 megapixels), resulting in digital images with a resolution of 3872 by 2592 pixels, which were subsequently modified. Soil profile was photographed and white reflection panels were used to balance and compensate differences in illumination. Rulers were attached to the profile to correct the image geometrically and assess the physical distribution of stained areas (Alaoui and Goetz, 2008).

Digital image analysis was performed using software GIMP 2.0 (GNU image manipulation software), which shows information about the statistical distribution of color values of the image that is currently active. Geometrical correction and maximization of blue, green, and cyan color were carried out with subsequent subtraction of background color and the conversion of images into grey scale tones. Finally, a median filter of $2 \mathrm{~cm}$ was applied and the vertical dye pattern was then analyzed with version 7.12.0 (R2011a) of Matlab (Mathworks Inc., Natick, Massachusetts, USA) according to Weiler and Flühler (2004) with stained path widths (SPW) $<20 \mathrm{~mm}$, 20-200 mm, and > $200 \mathrm{~mm}$, obtaining SPW profiles.

\section{Experimental design and statistic tests}

The experiment was in a completely randomized block design and $t$-Student tests were carried out to contrast soils with and without slurry applications in the same basin, besides a multiple component testing to assess the correlation between soil properties and $\mathrm{N}$ budgets. A backward stepwise procedure $(p<0.05)$ complemented this analysis.

To model and accurately predict the risk of groundwater pollution by nitrate leaching, a standard least square test was carried out and some linear regression fit models were obtained, defining the pedotransfer functions (PTFs). To improve these PTFs, some artificial neural networks (ANN) were estimated, according to accuracy indices. The determination coefficient $\left(\mathrm{R}^{2}\right)$ was complemented with the root mean square error (RMSE) and the sum of squared error of prediction (SSE). Finally, in the case of ANN, cross-validation was used through at least two values to validate the model.

\section{RESULTS AND DISCUSSION}

\section{Water budget and nitrate leaching}

The ETc values throughout the entire period were very low due to autumn-winter climate characteristics, fallow management and the sparse vegetation during the season, except in SS. As the soil water balance is very sensitive to evapotranspiration measurements (Ramos and Kücke, 1999), values of ETc in San Pedro soil (especially in SS) were considerably higher than at the other sites due to the presence and characteristics of the grown ryegrass-barleyoat crop.

Although any discussion about NL above the root zone could be perceived as meaningless, it can help understand nitrate movement through the soil profile, which is presumably intrinsically associated with water movement. Estimated NL values are presented in Table 3 considering the $\mathrm{N}$ budget (Equation [1]) and the model from Matus and Rodriguez (1994), assuming that gaseous losses (GL) occur when there is no net DP.

In Pichidegua soils, associated with slurry applications and irrigation, NL below $50 \mathrm{~cm}$ depth was considerably higher in PS than control soils with DP of 139.07 and $123.81 \mathrm{~mm}$, respectively. Although higher nitrate concentration in historically amended San Pedro soil (SS) than in control soil (SC) was observed, the nitrate budget showed significant differences only at $50 \mathrm{~cm}$ depth, with higher NL from $50 \mathrm{~cm}$ depth in SS. The low NL differences between San Pedro soils and even their simulated higher values in SC than SS are associated with high ETc in SS and the absence of irrigation and slurry applications in SC.

The NL values (Table 3) are within the range reported in Chile by Alfaro et al. (2006), observing values of 66-261 kg N ha ${ }^{-1}$ at control and $150 \mathrm{~kg} \mathrm{~N}^{-1}$ fertilized Andisol (lysimeters under $1260 \mathrm{~mm}$ of rainfall). However, 
Table 3. Nitrate leaching (NL) in two soils of central Chile and parameters used for this assessment.

\begin{tabular}{lccccc}
\hline Soil & $\mathrm{DP}$ & {$\left[\mathrm{N}-\mathrm{NO}_{3}{ }^{-}\right]^{\mathrm{a}}$} & $\mathrm{NL}_{\text {model }}{ }^{(\mathrm{b}, \mathrm{c})}$ & $\mathrm{NL}_{\text {budget }}$ & $\mathrm{GL}^{\mathrm{d}}$ \\
\cline { 4 - 6 } & $\mathrm{mm}$ & $\mathrm{mg} \mathrm{kg}^{-1}$ & & $\mathrm{~kg} \mathrm{ha}^{-1}$ & \\
\cline { 4 - 6 } PS 0 & 139.07 & $56.2 \pm 9.4$ & $58.8 \pm 12.1$ & $77.4 \pm 33.6$ & $27.4 \pm 32.6$ \\
PS 25 & 139.07 & $68.7 \pm 23.5$ & $97.8 \pm 29.0$ & $99.1 \pm 57.2$ & $49.8 \pm 48.2$ \\
PS 50 & 139.07 & $53.7 \pm 13.8 \mathrm{~b}$ & $106.7 \pm 12.8 \mathrm{~b}$ & $86.9 \pm 12.2 \mathrm{~b}$ & $62.2 \pm 30.8 \mathrm{~b}$ \\
PS 100 & 139.07 & $51.3 \pm 6.8 \mathrm{~b}$ & $48.1 \pm 7.7 \mathrm{~b}$ & $89.4 \pm 4.5 \mathrm{~b}$ & $40.6 \pm 42.2$ \\
PC 0 & 123.81 & $62.3 \pm 21.6$ & $52.8 \pm 18.3$ & $82.1 \pm 15.6$ & $8.7 \pm 7.5$ \\
PC 25 & 123.81 & $46.7 \pm 4.4$ & $71.9 \pm 12.9$ & $99.6 \pm 9.9$ & $30.2 \pm 21.9$ \\
PC 50 & 123.81 & $18.2 \pm 2.8 \mathrm{a}$ & $68.3 \pm 13.1 \mathrm{a}$ & $39.3 \pm 13.6 \mathrm{a}$ & $8.4 \pm 7.9 \mathrm{a}$ \\
PC 100 & 123.81 & $11.5 \pm 1.7 \mathrm{a}$ & $25.2 \pm 3.4 \mathrm{a}$ & $17.6 \pm 8.3 \mathrm{a}$ & $2.2 \pm 1.6$ \\
SS 0 & 43.40 & $21.3 \pm 4.2 \mathrm{~b}$ & $16.4 \pm 3.5$ & $18.3 \pm 9.5$ & $0.0 \pm 0.0$ \\
SS 25 & 43.40 & $15.5 \pm 2.2 \mathrm{~b}$ & $9.4 \pm 1.8 \mathrm{a}$ & $20.8 \pm 11.9$ & $0.0 \pm 0.0$ \\
SS 50 & 43.40 & $7.9 \pm 1.0$ & $5.6 \pm 2.1 \mathrm{a}$ & $24.8 \pm 10.1 \mathrm{~b}$ & $13.3 \pm 7.8 \mathrm{a}$ \\
SS 100 & 43.40 & $9.7 \pm 0.2 \mathrm{~b}$ & $1.5 \pm 0.6 \mathrm{a}$ & $16.6 \pm 6.3$ & $13.5 \pm 11.8$ \\
SC 0 & 78.11 & $11.8 \pm 2.6 \mathrm{a}$ & $13.8 \pm 1.8$ & $8.5 \pm 3.4$ & $0.5 \pm 0.6$ \\
SC 25 & 78.11 & $9.9 \pm 0.8 \mathrm{a}$ & $19.1 \pm 2.1 \mathrm{~b}$ & $14.5 \pm 4.9$ & $10.9 \pm 10.0$ \\
SC 50 & 78.11 & $7.0 \pm 0.4$ & $16.4 \pm 0.7 \mathrm{~b}$ & $5.8 \pm 4.7 \mathrm{a}$ & $26.2 \pm 2.4 \mathrm{~b}$ \\
SC 100 & 78.11 & $7.7 \pm 0.8 \mathrm{a}$ & $7.8 \pm 1.5 \mathrm{~b}$ & $17.0 \pm 7.8$ & $12.0 \pm 5.0$ \\
\hline
\end{tabular}

PS: Pichidegua with slurry additions; PC: Pichidegua control; SS: San Pedro with slurry additions; SC: San Pedro control.

${ }^{\mathrm{a}}$ Mean annual nitrate concentrations taken in soil auger samples (samples of $0.1 \mathrm{~m})$.

${ }^{b}$ Matus and Rodríguez (1994).

${ }^{c}$ Different lower-case letters between soils (same soil series) denote significant differences $(p<0.05)$.

${ }^{\mathrm{d}} \mathrm{DP}$ : deep percolation; GL: gaseous losses of N.

were considerably higher than those obtained by Salazar et al. (2010) in other Andisol (<4.2 $\left.\mathrm{kg} \mathrm{N} \mathrm{ha}^{-1}\right)$ with 400 $\mathrm{kg} \mathrm{N} \mathrm{ha-1}$ added as slurry and artificial fertilizers, mainly explained by gaseous losses and soil matrix retention. Claret et al. (2011) in an Alfisol under $1400 \mathrm{~mm}$ of rainfall, reported $\mathrm{NL}$ values $<7.9 \mathrm{~kg} \mathrm{~N}^{-1}$ but without significant differences between fertilized and control

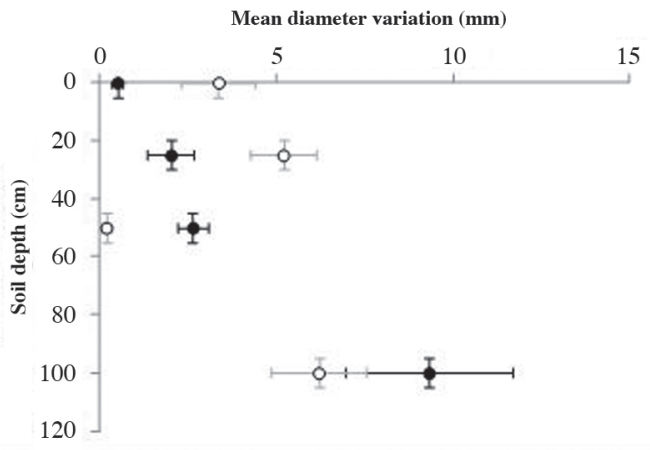

- PS

OPC

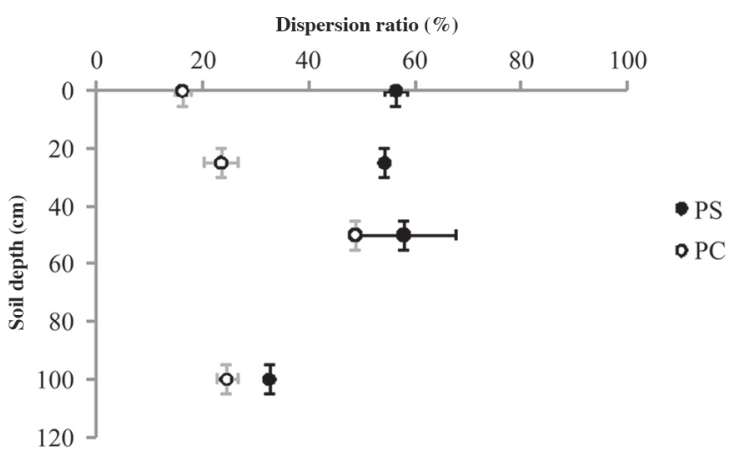

soils. In central Chile, Iriarte (2007) reported risks of NL in $27 \%$ of soils (Mollisols, Inceptisols, and Alfisols) and $63 \%$ of drinking water samples analyzed showed nitrate concentrations above the threshold prescribed by the INN (1984) of $10 \mathrm{mg} \mathrm{L}^{-1}$. In contrast, Arumi et al. (2005) observed that aquifers in the central valley of Chile do not contain significant nitrate concentrations associated with agricultural activity, inferring the existence of favorable conditions for the occurrence of natural attenuating processes such as denitrification. These contradictory NL results across Chilean soils are essentially explained by different management practices, soil properties, and water budgets.

Estimated gaseous losses (GL) of $\mathrm{N}$ showed considerably higher deviation than NL and were greater in PS than in PC, increasing until 50 and $25 \mathrm{~cm}$ depth, respectively, and decreasing subsequently. Restricted soil drainage and anoxic conditions in Pichidegua soils resulted in high values of denitrification. In San Pedro soils, GL were higher below $50 \mathrm{~cm}$ depth, but minimal above this depth due to oxidative conditions and soil structure development, as explained by Laudone et al. (2011).

Regression line (intersect and slope) between observed and predicted values $\left(\mathrm{R}^{2}: 0.6997\right)$ through a conditional sum of squares was not significantly different $(p<0.05)$ from 1:1 fit line. Thus $\mathrm{NL}_{\text {model }}$ and $\mathrm{NL}_{\text {budget }}$ assess the same phenomenon, with minor differences in the observed results. Nevertheless, it should be noted that at lower
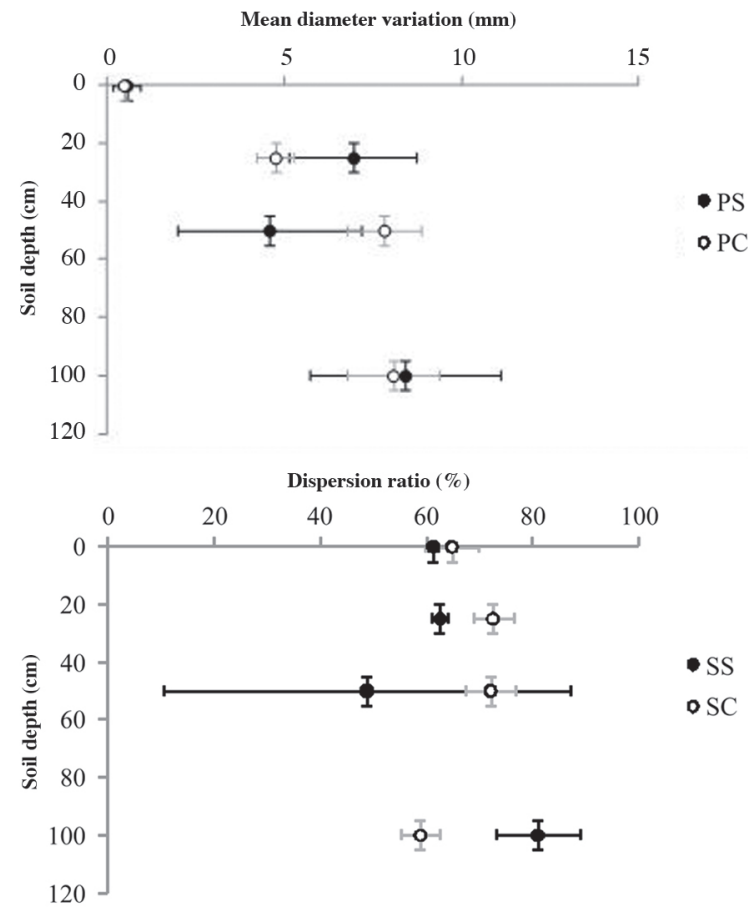

PS: Pichidegua with slurry additions; PC: Pichidegua control; SS: San Pedro with slurry additions; SC: San Pedro control.

Figure 3. Mean diameter variation as macroaggregate stability index (above) and dispersion ratio as a microaggregate stability index (below) in two soils of central Chile at different soil depths. Left: Pichidegua; Right: San Pedro. 
values, the model underestimated NL obtained by budget which can be attributed to experimental error, therefore more studies are needed to assess the reliability of the model.

\section{Soil structure and dynamic properties}

Mean diameter variation (MDV) as soil macroaggregate stability tended to decrease with depth in both soils, with exceptions as PC and SS at $50 \mathrm{~cm}$ depth (Figure 3), which showed low cohesion and similar mechanical behavior in wet and dry sieving. According to Yagüe et al. (2012), pig slurries applied over soils increase aggregate stability. Such was the case of PS above $25 \mathrm{~cm}$ depth, which showed lower MDV (higher macroaggregate stability) than PC $(p<0.05)$. The tendency for MDV to increase with depth is explained by the absence of conditions such as the wetting-drying cycles and organic matter (OM) accumulation/decomposition which occur at the surface, promoting low structure development in soil depth without the action of pedogenetic processes (Buol et al; 2011). More labile OM compounds play a major
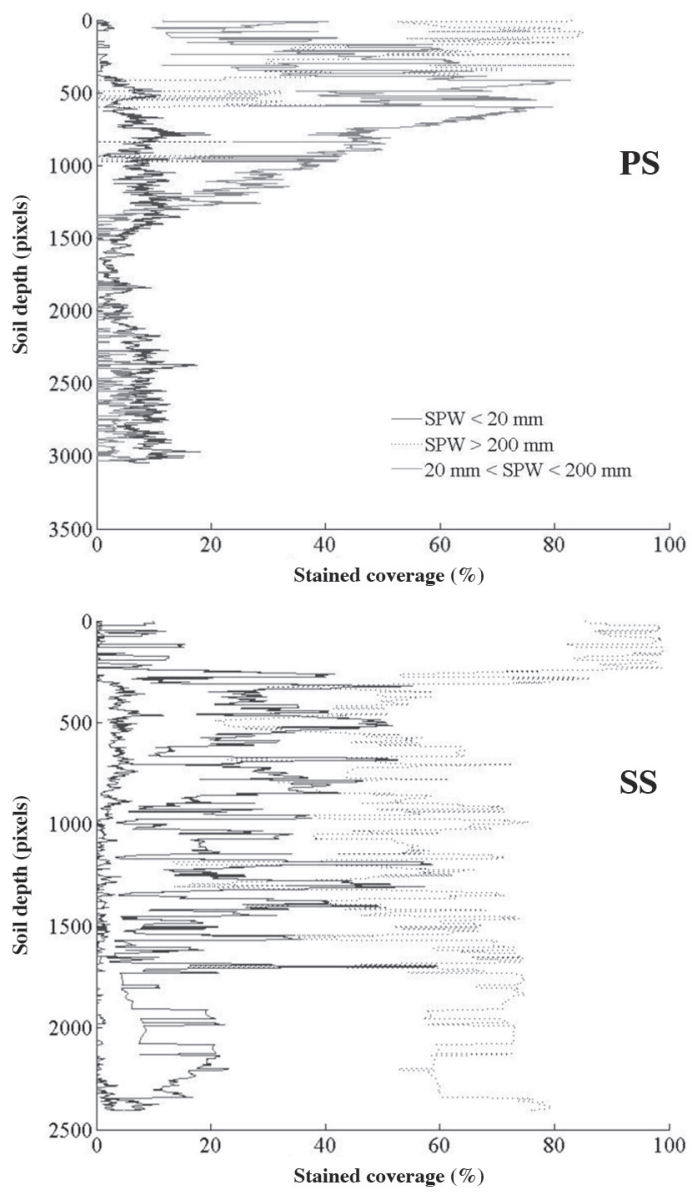

role through roots, fungal hyphae and polysaccharides from microorganisms that promote bonding between soil particles, improving macroaggregate stability (Ghezzehei, 2012).

Dispersion ratio (DR) as soil microaggregate stability index showed different behavior to MDV, being considerably higher in San Pedro pedons (Figure 3). This was associated with lower soil development or due to soil particle type, particularly sand particles, which in the absence of cementing agents and OM conferred low adhesion and cohesion. The binding of microaggregates appears to be relatively permanent and the OM associated with them is stabilized against decomposition (Yagüe et al., 2012). Recalcitrant OM compounds fill micropores and mesopores, resulting in higher stability of soil microaggregates compared with macroaggregates and lower values of DR in PC. Authors as Mbah and Onweremadu (2009) have reported that microaggregate stability does not increase with addition of organic amendments, in contrast to macroaggregate stability. Furthermore, OM compounds under natural
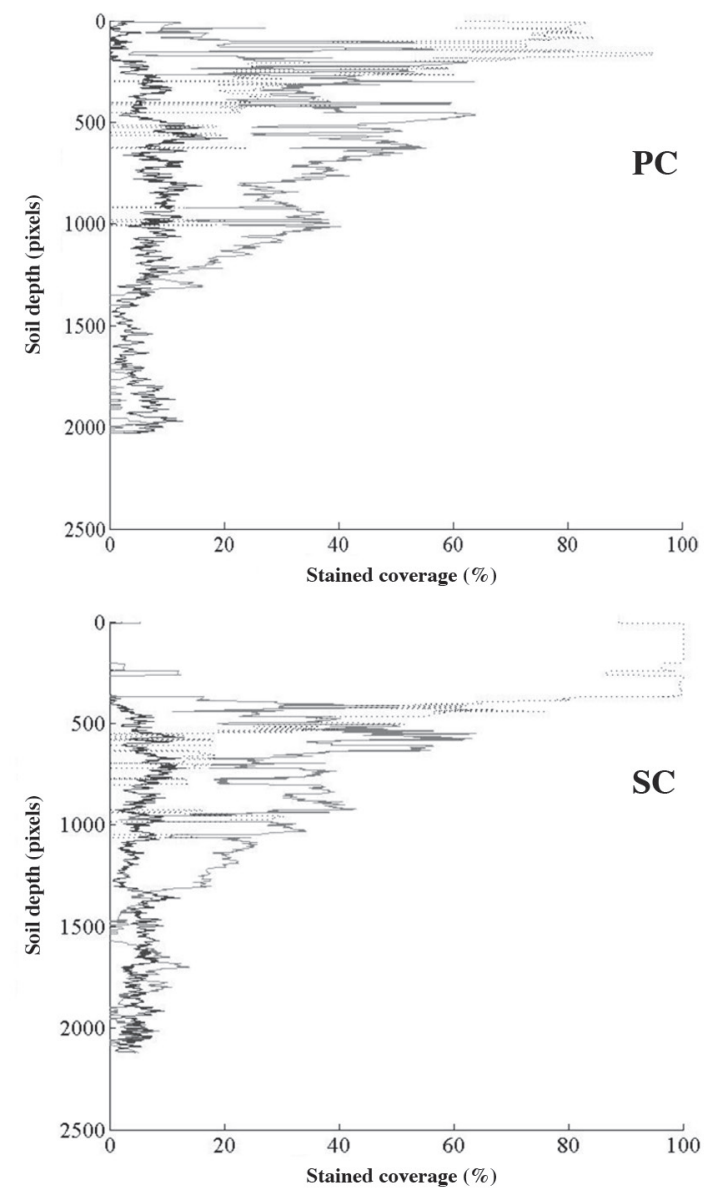

PS: Pichidegua with slurry additions; PC: Pichidegua control; SS: San Pedro with slurry additions; SC: San Pedro control; SPW: stained path widths.

Figure 4. Vertical stained path width pattern distributions in soils of central Chile. Above: Pichidegua soil profiles (control on right: 80 cm depth, slurry-amended on left: $110 \mathrm{~cm}$ depth). Below: San Pedro soil profiles (control on right: $110 \mathrm{~cm}$ depth, slurry-amended on left: $120 \mathrm{~cm}$ depth). 
conditions are translocated through pedoturbation, whilst under tillage such translocation occurs inside the first 30 $\mathrm{cm}$ of soil.

In San Pedro site there were no significant differences between soil management systems, but there was a tendency for higher macroaggregate stability and lower microaggregate stability in the control soil (SC), except at 50 and $100 \mathrm{~cm}$ depth, where external factors almost do not promote soil genesis.

\section{Preferential flow and pedotransfer functions (PTFs) for nitrate leaching}

The distribution of stained path width (SPW) is a 2D morphometrical property which describes the width of the stained flow pathway, allowing classifying the kind of flow (macropores or matrix flow) that predominates in the soil. The pattern distribution showed (Figure 4) a regular decrease in stained coverage with depth, especially in $\mathrm{PC}$ and SC. There was a marked decrease in $\mathrm{SPW}_{200}$, but this was compensated for by a sharp increase in $\mathrm{SPW}_{20}$ at depth, except in SS. In general, $\mathrm{SPW}_{20-200}$ values increased between 25 and $50 \mathrm{~cm}$ soil depth.

In Pichideguathe two SPW profiles showed considerable similarities, with $\mathrm{SPW}_{200}$ being more homogeneous and deeper in the arable top layer of PS, whilst SPW $20-200$ and $\mathrm{SPW}_{20}$ showed a common distribution pattern in the two soil profiles, but with a higher proportion of $\mathrm{SPW}_{20-200}$ in PS. The SPW distributions in San Pedro showed clear differences between soil conditions. Areas with $\mathrm{SPW}_{200}$ were widespread through the entire SS vertical profile, although higher in the arable soil top layer, whilst in SC they were confined to the top layer. In general, control soils show more heterogeneous kind of flow in depth than soils with pig slurry.

The pedotransfer function for $\mathrm{NL}\left(\mathrm{kg} \mathrm{ha}^{-1}\right)$ linked to basic physical soil properties from different depths in all soils was $\left(p<0.0001 ; \mathrm{R}^{2}=0.89 ; \mathrm{RMSE}=13.289\right)$ :

$$
\begin{aligned}
& \mathrm{NL}_{\text {budget }}=-67.2+77.0(\mathrm{SDP})+131.0(\mathrm{TP})+1.6(\mathrm{MDV}) \\
& +1.5\left(\mathrm{~N}-\mathrm{NO}_{3}{ }^{-}\right)+0.2\left(\log _{10} \mathrm{Ka}_{33}\right)
\end{aligned}
$$

where SDP corresponds to slow draining porosity $\left(\mathrm{cm}^{3} \mathrm{~cm}^{-3}\right)$, TP is textural porosity (\%), MDV is mean diameter variation $(\mathrm{mm})$ as a macroaggregate stability index, $\mathrm{N}_{-\mathrm{NO}_{3}}^{-}$is nitric $\mathrm{N}$ concentration $\left(\mathrm{mg} \mathrm{kg}^{-1}\right)$ and $\mathrm{Ka}_{33}$ corresponds to air conductivity at $33 \mathrm{kPa}$ of water tension $\left(\mathrm{m} \mathrm{d}^{-1}\right)$. All studied soils showed moderate to very fast saturated hydraulic conductivity (McKenzie et al., 2002) and a domain of TP (Figure 2) that enhances the infiltrability processes. Besides, the inverse relationship between MDV and NL demonstrates that elevated macroaggregate stability (low MDV values) in the studied soils reduced NL. An increase in macroaggregate stability must be interpreted as a consequence of nitrogen immobilization, which cause that a variety of released nitrogen compounds be used in the synthesis of humic matter and microorganisms tissues (Tan, 2003), these are responsible in aggregates stability (Six et al., 2004), decreasing the nitrates availability, and the risk of NL. On the other hand, both SDP and $\mathrm{Ka}_{33}$ clearly denote the particular functionality of soil pores by size, because a higher diameter and connectivity of pores enhances the water flow capacity, which consequently drives higher solute movement. Finally, an expected direct relationship (Kleber et al., 2000) between $\mathrm{N}^{-\mathrm{NO}_{3}}{ }^{-}$concentration and NL is observed.

Applying a Gauss Newton artificial neural network (ANN) with 58-fold cross-validation $(\mathrm{n}=64)$ to improve the relations obtained through the least square fit model gave some better adjustment of parameters due to non-linearity of the data (Figure 5). The hidden nodes applied to obtain the models were denoted $\mathrm{H} 1$, $\mathrm{H} 2$, and $\mathrm{H} 3$.

By assessing mean values of NL at a same depth of measurement for each site, other PTF was obtained ( $p<$ $\left.0.0001 ; \mathrm{R}^{2}=0.93 ; \mathrm{RMSE}=10\right)$ :

$$
\mathrm{NL}_{\text {budget }}=8.8+1.5\left(\mathrm{~N}-\mathrm{NO}_{3}{ }^{-}\right)-0.2 \mathrm{SPW}_{200}
$$

where $\mathrm{SPW}_{200}$ corresponds to stained path width $>200$ $\mathrm{mm}(\%)$.

Again, using ANN with a 14-fold cross-validation (n =16), the Gauss Newton method improved the model assessed previously due to its non-linearity (Figure 6). The $\mathrm{SPW}_{200}$ value is related to matrix flow type, which allows the soil solution to interact greatly with the soil matrix, inducing an inverse relationship with NL.

The above models allowed the levels of NL to be predicted accurately, even through two or three variables,

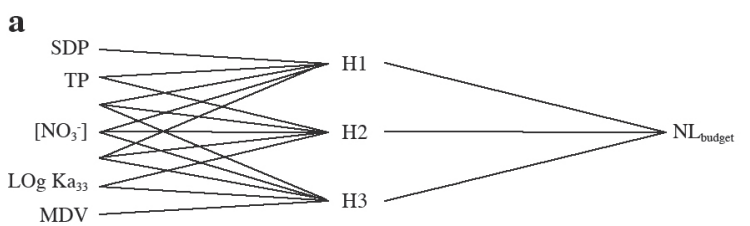

b

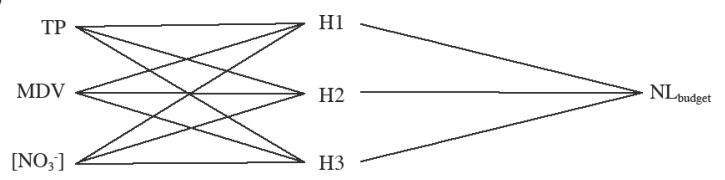

Figure 5. Artificial neural network diagrams to predict budget nitrate leaching $\left(N_{\text {budget }}\right)$ with three hidden nodes. (a) $\mathbf{N L}_{\text {budget }}$ with squared error of prediction (SSE) scaled: 2.49 , root mean squared error (RMSE) scaled: 0.200 , and $R^{2}: 0.96$. (b) $N_{\text {budget }}$ with SSE scaled: 4.83, RMSE scaled: 0.284 , and $R^{2}: 0.92$.
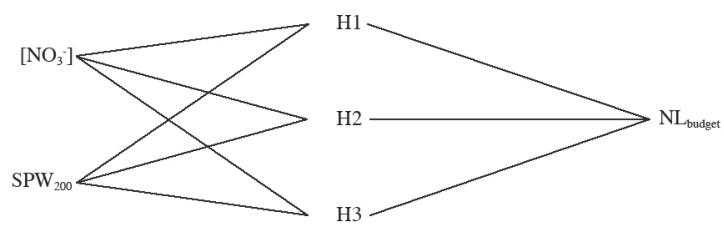

SPW: Stained path widths.

Figure 6. Artificial neural network diagrams to predict budget nitrate leaching $\left(\mathrm{NL}_{\text {budget }}\right)$ with three hidden nodes. $\mathrm{NL}_{\text {budget }}$ with squared error of prediction (SSE) scaled: 0.22 , root mean squared error (RMSE) scaled: 0.136 , and $R^{2}: 0.99$. 
which thus served as soil physical functions to assess the susceptibility of soils to cause groundwater pollution by $\mathrm{NL}$. Although the selected variables, especially $\mathrm{SPW}_{200}$, hinder the model application in field conditions, the present study generated new information of the soil matrix interaction and the NL risk, having projections to be used at sub basin level with contrasting soils. Thus further studies must be carried out at basin or even greater scale and should also comprise geomorphological and geological factors, to gain a better understanding of the relationships between soil properties and pollute leaching associated with slurry applications and to obtain a general model for predicting NL, thus advancing hydropedological field studies.

\section{CONCLUSIONS}

Nitrate leaching (NL) is associated with several soil properties. Soil structure and particle size distribution are fundamental to understanding complex water flow processes that lead to solute movement through pedons. Hence, many physical and hydraulic soil properties can be used to predict or model NL. Dye tracer tests provide a better understanding of water flow types and water movement patterns through soils.

Pedotransfer functions were obtained to predict NL based on soil morpho-physical properties. These showed that textural porosity, mean diameter variation, amount of slow draining pores, macropore continuity (evaluated as air permeability at $33 \mathrm{kPa}$ water tension) and $\mathrm{N}^{-\mathrm{NO}_{3}}{ }^{-}$ soil concentration were positively related to NL. Stained path width $>200 \mathrm{~mm}$ was negatively related to NL in the studied soils.

Artificial neural network analysis proved to be a better method than least square fit models, giving higher accuracy and smaller errors in the prediction of solutes movement through soils due to the non-linearity of such process.

Using only two or three variables as soil physical factors, the used models allowed to predict accurately the levels of NL and to assess soil susceptibility to cause groundwater pollution by NL. Despite the difficulty to apply the selected variables, its use could be applied in sub-basin studies and precision agriculture.

\section{ACKNOWLEDGEMENTS}

Work supported by the Servicio Agrícola y Ganadero (SAG-Chile), Livestock Protection Department and partial funding from the Program U-Apoya Project nr 11/09, University of Chile.

\section{LITERATURE CITED}

Alaoui, A., U. Caduff, H.H. Gerke, and R. Weingartner. 2011. Preferential flow effects on infiltration and runoff in grassland and forest soils. Vadose Zone Journal 10:367-377.
Alaoui, A., and B. Goetz. 2008. Dye tracers and infiltration experiments to investigate macropore flow. Geoderma 144:279286.

Alfaro, M., F. Salazar, D. Endress, J. Dumont, and A. Valdebenito. 2006. Nitrogen leaching losses on a volcanic ash soil as affected by the source of fertilizer. Revista de la Ciencia del Suelo y Nutrición Vegetal 6:54-63.

Arumi, J., R. Oyarzún, and M. Sandoval. 2005. Natural protection against groundwater pollution by nitrates in the Central Valley of Chile. Hydrological Sciences Journal 50:331-340.

Berryman, C., D. Davies, C. Evans, M. Harrod, A. Hughes, R. Skinner, et al. 1982. Techniques for measuring soil physical properties. Formerly Advisory Paper nr 18. Reference Book 441. Ministry of Agriculture, Fisheries and Food, Stokholm, Sweden.

Buczko, U., R. Kuchenbuch, and B. Lennartz. 2010. Assessment of the predictive quality of simple indicator approaches for nitrate leaching from agricultural fields. Journal of Environmental Management 91:1305-1315.

Buol, S.W., R.J. Southard, R.C. Graham, and P.A. McDaniel. 2011. Soil genesis and classification. $6^{\text {th }}$ ed. John Wiley \& Sons Ltd., Oxford, UK

Casanova, M., O. Salazar, O. Seguel, and W. Luzio. 2013. The soils of Chile. In Hartemink, A. (ed.) World Soils Book Series. Springer Science+Business Media, Dordrecht, The Netherlands.

Claret, M., R. Urrutia, R. Ortega, S. Best, and N. Valderrama. 2011. Quantifying nitrate leaching in irrigated wheat with different nitrogen fertilization strategies in an Alfisol. Chilean Journal of Agricultural Research 71:148-156.

Clothier, B.E., S.R. Green, and M. Deurer. 2008. Preferential flow and transport in soil: Progress and prognosis. European Journal of Soil Science 59:2-13.

Ghezzehei, T.A. 2012. Soil Structure. p. 1-17. In Huang, P., Y. Li, and M. Sumner (eds.) Handbook of Soil Science. Vol. 2. CRC Press, Boca Raton, Florida, USA.

Hartge, K.H., und R. Horn. 1992. Die physikalische Untersuchung von Boden. Ferdinand Enke Verlag, 3. Auflage, Germany.

Harter, T., H. Davis, M. Mathews, and R. Meyer. 2002. Shallow groundwater quality on dairy farms with irrigated forage crops. Journal of Contaminant Hydrology 55:287-315.

INN. 1984. Norma chilena oficial para agua potable, NCh 409. Instituto Nacional de Normalización (INN), Santiago, Chile.

Iriarte, A. 2007. Evaluación espacial de la lixiviación potencial de nitratos en suelos de la subcuenca del río Cachapoal bajo. Memoria de título profesional Geógrafo. Universidad de Chile, Facultad de Arquitectura y Urbanismo, Santiago, Chile.

Jarvis, N.J. 2007. A review of non-equilibrium water flow and solute transport in soil macropores: Principles, controlling factors and consequences for water quality. European Journal of Soil Science 58:523-546.

Kleber, M., P. Nikolaus, Y. Kuzyakov, and K. Stahr. 2000. Formation of mineral $\mathrm{N}\left(\mathrm{NH}_{4}{ }^{+}, \mathrm{NO}_{3}{ }^{-}\right)$during mineralization of organic matter from coal refuse material and municipal sludge. Journal of Plant Nutrition and Soil Science 163:73-80.

Kolberg, R.L., B. Rouppet, D.G. Westfall, and G.A. Peterson. 1997. Evaluation of an in situ net soil nitrogen mineralization in dryland agroecosystems. Soil Science Society of America Journal 61:504508 .

Laudone, G.M., G.P. Matthews, N.R.A. Bird, W.R. Whalley, L.M. Cardenas, and A.S. Gregory. 2011. A model to predict the effects of soil structure on denitrification and $\mathrm{N}_{2} \mathrm{O}$ emission. Journal of Hydrology 409:283-290.

Mastrocicco, M., N. Colombani, and G. Castaldelli. 2013. A stepwise approach to assess the fate of nitrogen species in agricultural lowlands. p. 431-460. In Sharma, S.K., and R. Sanghi (eds.) Wastewater reuse and management. Springer Science+Business Media, Dordrecht, The Netherlands

Matus, F.J., and J. Rodríguez. 1994. A simple model for estimating the contribution of nitrogen mineralization to the nitrogen supply of crops from a stabilized pool of soil organic matter and recent organic input. Plant and Soil 162:259-271. 
Mbah, C.N., and E. Onweremadu. 2009. Effect of organic and mineral fertilizer inputs on soil and maize grain yield in an acid Ultisol in Abakaliki-South Eastern Nigeria. American Eurasia Journal of Agronomy 2:7-12.

McKenzie, N., K. Coughlan, and H. Cresswell. 2002. Soil physical measurement and interpretation for land evaluation. CSIRO, Melbourne, Australia.

Pizarro, R., R. Valdés, P. García-Chevesich, C. Vallejos, C. Sangüesa, C. Morales, et al. 2012. Latitudinal analysis of rainfall intensity and mean annual precipitation in Chile. Chilean Journal of Agricultural Research 72:252-261.

Ramos, C., y M. Kücke. 1999. Revisión crítica de los métodos de medida de la lixiviación de nitrato en suelos agrícolas. p. 25-32. In Muñoz-Carpena, R., A. Ritter, and C. Tascón (eds.) Estudios de la zona no saturada del suelo. Instituto Canario de Investigaciones Agrarias (ICIA), Tenerife, España.

Sadzawka, M.A., M.A. Carrasco, R. Demanet, H. Flores, R. Grez, M.L. Mora, et al. 2007. Métodos de análisis de tejidos vegetales. $2^{\mathrm{a}}$ ed. Serie Actas INIA nr 40. Instituto de Investigaciones Agropecuarias INIA, Santiago, Chile.

Sadzawka, M.A., M.A. Carrasco, R. Grez, M.L. Mora, H. Flores, y A. Neaman. 2006. Métodos de análisis de suelos recomendados para los suelos de Chile. Serie Actas INIA $N^{\circ} 34$. Instituto de Investigaciones Agropecuarias INIA, Santiago, Chile.

Salazar, F., M. Alfaro, T. Misselbrook, and J. Lagos. 2010. Nitrogen leaching following a high rate of dairy slurry application on a ryegrass sward of a volcanic soil in southern Chile. p. 48-55. In Marques dos Santos Cordovil, C.S.C., and L. Ferreira (eds.) Losses on application and storage. environmental, nutrient losses, impact of storage and spreading operations. Proceedings of the $14^{\text {th }}$ Ramiran International Conference, Lisboa. 12-15 September. Universidade Técnica de Lisboa, Instituto Superior de Agronomia, Tapada da Ajuda, Lisboa, Portugal.
Salemi, E., N. Colombani, V. Aschonitis, and M. Mastrocicco. 2011. Assessment of specific vulnerability to nitrates using LOS indices in the Ferrara Province, Italy. p. 283-290. In Lambrakis, N., G Stournaras, and K. Katsanou (eds.) Advances in the research of aquatic environment 2. Springer-Verlag, Berlin, Germany.

Scheffer, B., und U. Ortseifen. 1997. Zur Abschatzung des Nitrataustrags in die Gewasser am Beispiel der Boden Niedersachsens. p. 61-70. In Brunswick Groundwater Colloquium 1997. Environmentally Friendly Management of Groundwater and Soil, Braunschweig, Germany.

Shein, E.V., and T.A. Arkhangel'skaya. 2006. Pedotransfer functions: state of the art, problems, and outlooks. Eurasian Soil Science 39:1089-1099.

Six, J., H. Bossuyt, S. Degryze, and K. Denef. 2004. A history of research on the link between (micro)aggregates, soil biota, and soil organic matter dynamics. Soil and Tillage Research 79:7-31.

Tan, K. 2003. Humic matter in soil and the environment. Principles and controversies. Marcel Dekker, New York, USA.

Vahtera, E., D. Conley, B. Gustafsson, and H. Kuosa. 2007. Internal ecosystem feedbacks enhance nitrogen fixing cyanobacteria blooms and complicate management in the Baltic Sea. Ambio 36:186-194.

Weiler, M., and H. Flühler. 2004. Inferring flow types from dye patterns in macroporous soils. Geoderma 120:137-153.

Yagüe, M.R., A.D. Bosch-Serra, M. Antúnez, and J. Boixadera 2012. Pig slurry and mineral fertilization strategies' effects on soil quality: Macroaggregate stability and organic matter fractions. Science of the Total Environment 438:218-224 